\title{
PREVALENCE OF MUSCULOSKELETAL PROBLEMS
} AMONG FULL TIME LADY SERVANTS

\author{
IN DOQQI AREA, CAIRO
}

\author{
By \\ El Tayeb IM, Ghareeb NS and Zalat MM \\ Department of Community, Occupational and Environmental Medicine, Faculty of Medicine, \\ Zagazig University, Egypt
}

\begin{abstract}
Introduction: Musculoskeletal disorders (MSDs) have been identified as a major health concern affecting sizeable segments of the general and working populations. A limited number of studies have particularly explored the prevalence and causes of MSDs among full-time lady servants who routinely perform housework. Aim of work: To estimate the prevalence and pattern of musculoskeletal disorders among randomly selected lady servants and to identify potential factors associated with selfreported musculoskeletal disorders (MSD) among full-time lady servants in Doqqi area, Cairo. Materials and Methods: It is a cross-sectional study included randomly selected female servants in Doqqi area, Cairo. Nordic Musculoskeletal Questionnaire (NMQ) was used to study frequency of MSD and possible risk factors associated with it. Results: The study revealed that all the studied population are female, illiterate (70.4\%), unmarried $(57.8 \%$ ), and $43.7 \%$ of them have $\geq 3$ children. As well as $76.1 \%$ of lady servants are working using repetitive movements and $69 \%$ taking awkward positions during domestic work. Eighty four percent $(84.5 \%)$ of the study group had musculoskeletal troubles during past 12 months, mostly in lumbar region $(63.3 \%)$ and $36.6 \%$ of servants have evidence of stress. Conclusions: A major finding of this study was musculoskeletal disorders $(84.5 \%)$ that mainly affected lumbar area followed by knee, wrist and hand areas. Also, 56.3\% of servants had mental stress and the most important risk factors that affect the MSDs were awkward positions and repetitive movements.
\end{abstract}

Keywords: Domestic labor; Servants; Female; Musculoskeletal disorders.

Conflict of interest: None

Funding: This research did not receive any specific grant from any funding agency in the public, commercial or not-for-profit sector. 


\section{Introduction}

Musculoskeletal disorders (MSDs) have been identified as a major health concern affecting sizeable segments of the general and working populations [National Research Council, 2001; Muirden, 2005] due to their high impact on personal suffering, absence from work, disability, and their direct and indirect costs to the health care system [Picavet \& Shouten, 2003].

Most work-related musculoskeletal disorders (WRMSDs) develop over time and are caused either by the work itself or by the employees' working environment. Health problems range from discomfort, minor aches, pains, inflammatory and degenerative diseases of the locomotor system, such as inflammations of tendons, pain and functional impairments of muscles, compression of nerves, to more serious medical conditions requiring time off work and even medical treatment. In more chronic cases, treatment and recovery are often unsatisfactory, and the result could be permanent disability and loss of employment [European Agency for Safety and Health at Work, 2010].

The multifactorial causation of WRMSDs is commonly acknowledged.
Different groups of risk factors including physical and mechanical factors, organizational and psychosocial factors, and individual and personal factors may contribute to the genesis of WRMSDs. Repetitive handling at high frequency, awkward and static postures, demanding and straining work and lack of recreation times, high time pressure, frequently overtime hours, repetitive or monotonous work, reduced physical capacity, obesity, and smoking are all the risk factors that contribute to WRMSDs either each one solely or by interacting each other [European Agency for Safety and Health at Work, 2010].

Domestic labor (including housework and care activities) and the home environment have been generally ignored when addressing MSDs. A limited number of studies have particularly explored the prevalence and causes of MSDs among full-time, part-time, or unemployed homemakers who routinely perform housework [Yip et al., 2001, 2004; Rosano et al., 2004].

This occupational sector which remains largely unexplored in Egypt is characterized by high physical and psychosocial demands and the staff is typically female [Brulin et al., 2000]. 
Physical work demands associated with these disorders include heavy physical work in general such as heavy lifting, repetitive work [Punnett and Wegman 2004], prolonged standing, especially without access to seats [Arcand et al., 2000; Laperriere et al., 2006], neck flexion [Ariens et al., 2001], work with abducted arm (or arm above shoulder level) [Viikari-Juntura et al., 2001], bending or twisting [National Research Council, 2001], exposure to wholebody and hand-arm vibration [Ariens et al., 2000].

Work is a major determinant of these disorders, and exposures in paid work have been associated with back, neck [Ariens et al., 2000; Messing et al., 2009], shoulder, and upper- and lower-limb disorders [Messing et al., 2006]. The effect of poor postures will continue unless proactive steps are taken to evaluate and reduce the problem. More suitable working postures may have a positive effect on workers' musculoskeletal systems and may allow for more effective control of work performance and reduction in the number of occupational problems [Mattila and Vilkki, 1999].

\section{Aim of Work}

The aim of this cross-sectional study was to estimate the prevalence and pattern of musculoskeletal disorders among randomly selected female home care personnel or servants and to identify the potential related risk factors for MSD in Doqqi area in Cairo. Attention has been given to known biomechanical risk factors (heavy physical work, prolonged sitting, prolonged standing, repetitive work, upper-limb abduction, bending, twisting, and neck flexion) associated with MSDs, and likely to be found in housework.

\section{Materials and Methods}

\section{Study design and setting:}

A cross sectional study was conducted among homemakers randomly selected from homemakers' offices from 3 licensed companies distributed in Doqqi area, Cairo from 1st May 2012 through 1st August 2012. Totally, 178 females were employed in these offices. In this study, our inclusion criteria - female with age range 18 till 45 years old. -With at least one year of job. Our exclusion criteria were for servants with background diseases or accidents affecting musculoskeletal system were excluded from the study. 94 lady servants fit the inclusion and exclusion criteria of this study. A pilot study was conducted on 10 homemakers, who were excluded from 
the main study, to test the measures and then modifications were carried out to improve clarity and convenience. The remaining 84 female homemakers were eligible to participate, 13 of them refuse to participate in the study so 71 lady servants who finally participate in the study.

\section{Data collection:}

The data were collected using face to face questionnaire which consisted of two parts and covered the following items: a) personal details (including age, weight, marital status, educational level, number of children, salary, duration of employment, repetitive movements and awkward positions during work lastly, health and medical background); and b) musculoskeletal problems in different body regions. The standard Nordic Questionnaire of musculoskeletal symptoms (NMQ) [Kuorinka et al., 1987] was used to examine reported cases of MSDs among the study population. Reported MSDs symptoms were limited to the past 12 months. The overall response was $84.5 \%$.

Mental health was assessed by measuring distress, using the General Health Questionnaire (12 item) version of (Goldberg \& Williams, 1988), which has been validated in Arab countries
(El Rufaie \& Daradkeh, 1996). General Health Questionnaire scoring depends on Scoring - Likert Scale 0, 1, 2, 3 styles from up to down and composed of 12 items, (able to concentrate, lost much sleep, over worry, playing a useful part in things, capable of making decisions, felt constantly under strain, could not overcome difficulties, enjoy your normal activities, able to face up problems, feeling unhappy and depressed, losing confidence in yourself, thinking yourself worthless, feeling reasonably happy), each item take from (0-3 score) and the total score range from (0 to 36). Score $>15$ evidence of distress and Score $>20$ suggests severe problems and psychological distress.

Data management: The collected data were presented, summarized, tabulated \& analyzed by using computerized software statistical packages (EPI-info Version 6.04 \& SPSS version 19). (IBM, 2010). A p-value $<0.05$ was considered statistically significant.

Ethical issues: Before interview, professional servants were informed of the general aim of the study and their participation in the study was fully voluntary. Informed consent has been obtained. Confidentiality of collected data was guaranteed to participants. 


\section{Results}

Table (1): Frequency distribution of some socio-demographic, BMI and occupational data among lady servants.

\begin{tabular}{|c|c|c|}
\hline \multirow[t]{2}{*}{ Socio-demographic characteristics } & \multicolumn{2}{|c|}{$\begin{array}{c}\text { Lady Servants } \\
(\mathrm{n}=71)\end{array}$} \\
\hline & No. & $(\%)$ \\
\hline $\begin{array}{r}\text { Age (years): } \\
-\quad \leq 40 \\
-\quad>40\end{array}$ & $\begin{array}{c}66 \\
5\end{array}$ & $\begin{array}{c}92.9 \\
7.1\end{array}$ \\
\hline \begin{tabular}{ll}
\multicolumn{2}{l}{ Level of education: } \\
- & Illiterate \\
- & Read and write \\
- & Primary education
\end{tabular} & $\begin{array}{c}50 \\
18 \\
3\end{array}$ & $\begin{array}{c}70.4 \\
25.4 \\
4.2\end{array}$ \\
\hline \begin{tabular}{ll}
\multicolumn{2}{l}{ Income: } \\
$-\quad$ Enough. \\
$-\quad$ & Not enough. \\
\end{tabular} & $\begin{array}{l}40 \\
31 \\
\end{array}$ & $\begin{array}{l}56.3 \\
43.7 \\
\end{array}$ \\
\hline \begin{tabular}{ll}
\multicolumn{2}{l}{ Smoking status: } \\
$-\quad$ Smokers \\
$-\quad$ Non smokers \\
\end{tabular} & $\begin{array}{c}2 \\
69\end{array}$ & $\begin{array}{c}2.8 \\
97.2\end{array}$ \\
\hline $\begin{array}{ll}\text { Body } & \text { Mass Index }(\mathbf{k g} / \mathbf{m} 2): \\
- & \text { Under weight } \\
- & \text { Normal weight } \\
- & \text { Over weight } \\
- & \text { Obese } \\
\end{array}$ & $\begin{array}{c}10 \\
25 \\
35 \\
1\end{array}$ & $\begin{array}{r}14.0 \\
35.3 \\
49.3 \\
1.4\end{array}$ \\
\hline 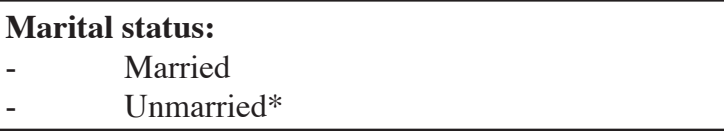 & $\begin{array}{l}30 \\
41\end{array}$ & $\begin{array}{l}42.2 \\
57.8\end{array}$ \\
\hline $\begin{array}{l}\text { Children number: } \\
\text {-no children } \\
-1-2 \text { child } \\
-\geq 3 \text { child }\end{array}$ & $\begin{array}{l}14 \\
26 \\
31\end{array}$ & $\begin{array}{l}19.7 \\
36.6 \\
43.7\end{array}$ \\
\hline $\begin{array}{l}\text { Duration of work(year): } \\
-\quad \leq 20 \\
-\quad>20\end{array}$ & $\begin{array}{c}64 \\
7\end{array}$ & $\begin{array}{c}90.1 \\
9.9\end{array}$ \\
\hline 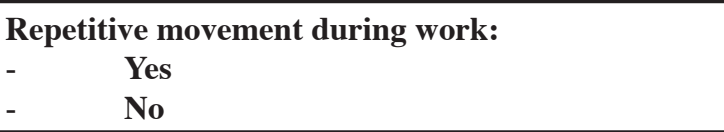 & $\begin{array}{l}54 \\
17\end{array}$ & $\begin{array}{l}76.1 \\
23.9\end{array}$ \\
\hline $\begin{array}{l}\text { Awkward positions (kneeling- bending-squatting): } \\
-\quad \text { Yes } \\
-\quad \text { No }\end{array}$ & $\begin{array}{l}49 \\
22\end{array}$ & $\begin{array}{l}69 \\
31\end{array}$ \\
\hline
\end{tabular}

* including single and widow servants. 
This table shows the demographic characteristics among the study group ( full time lady servants), where $92.9 \%$ of the study group are relatively young below 40 years old ,all of them were female ,70.4\% of them are illiterate, $56.3 \%$ of them claims enough income only $2.8 \%$ of them are smokers. Almost half of them are overweight $(49.2 \%)$, most of them are unmarried $(57.8 \%), 43.7 \%$ of them have $\geq 3$ children and $90.1 \%$ of them their duration of work less than 20 years. As well as $76.1 \%$ of lady servants are working using repetitive movements and $69 \%$ taking awkward positions during domestic work.

Table (2): Frequency distribution of Nordic questionnaire survey among study group for detection of MSD.

\begin{tabular}{|l|c|c|}
\hline \multicolumn{1}{|c|}{ Nordic questionnaire survey } & \multicolumn{2}{|c|}{$\begin{array}{c}\text { Full time lady servants } \\
(\mathbf{n}=71)\end{array}$} \\
\cline { 2 - 3 } & No. & \\
\hline $\begin{array}{l}\text { 1- Have you at any time during past 12 months had trouble } \\
\text { (Ache- pain-discomfort): }\end{array}$ & & \\
Yes & 60 & 84.5 \\
No & 11 & 15.5 \\
Have you at any time during past 12 months being prevented \\
from doing your normal work (at home or away from home) \\
because of the troubles: (N=60) & & \\
Yes & 39 & 65 \\
No & 21 & 35 \\
\hline 2- Have you had trouble at any time during past 7 days: & 55 & 77.5 \\
Yes & 16 & 22.5 \\
No & & \\
\hline
\end{tabular}

This table shows that $84.5 \%$ of the study group had trouble (ache- paindiscomfort ) at any time during past 12 months , 65\% from them being prevented from doing their normal work due to that trouble in the same period (last 12 months) and $77.5 \%$ of servants had that trouble at any time during the last 7 days . 
Table (3): Frequency distribution of MSDs according to affected body region.

\begin{tabular}{|l|c|c|}
\hline \multirow{2}{*}{ Body region } & \multicolumn{2}{|c|}{$\begin{array}{c}\text { Servants } \\
\text { (n=60) }\end{array}$} \\
\cline { 2 - 3 } & No. & $(\%)$ \\
\hline Lumbar & 38 & 63.3 \\
\hline One or both knees & 28 & 46.7 \\
\hline Upper back & 20 & 33.3 \\
\hline Shoulder & 15 & 25 \\
\hline Wrist and hand & 14 & 23.3 \\
\hline One or both ankle/ feet & 22 & 36.7 \\
\hline One or both hip / thigh & 10 & 16.7 \\
\hline Elbow & 7 & 11.7 \\
\hline
\end{tabular}

This table shows that the highest prevalence of musculoskeletal disorders is at lumbar region $(63.3 \%)$ of the study group followed by one or both knees $(46.7 \%)$ then wrist and hand $(36.7 \%)$ and the least prevalence is $(8.3 \%)$ at elbow region.

Table (4): Classification of General Health Questionnaire scoring system.

\begin{tabular}{|l|c|c|}
\hline \multirow{2}{*}{ General Health Questionnaire score } & \multicolumn{2}{|c|}{$\begin{array}{c}\text { Servants } \\
(\mathbf{n = 7 1})\end{array}$} \\
\cline { 2 - 3 } & No. & $(\boldsymbol{\%})$ \\
\hline No stress: $\quad$ score $\leq \mathbf{1 5}(\mathbf{0 - 1 5})$ & 31 & $43.7 \%$ \\
\hline Evidence of stress: $\quad($ Score $>\mathbf{1 5}) \mathbf{( 1 6 - 2 0 )}$ & 26 & $36.6 \%$ \\
\hline Severe stress $\quad$ score $>\mathbf{2 0})(\mathbf{2 1 - 3 6})$ & 14 & $19.7 \%$ \\
\hline
\end{tabular}

This table shows that $36.6 \%$ of servants have evidence of stress and $19.7 \%$ have severe stress. 
Table (5): Variables associated with MSD by multiple logistic regressions.

\begin{tabular}{|c|c|c|}
\hline \multirow{2}{*}{ Socio-demographic characteristics and distress } & \multicolumn{2}{|c|}{$\begin{array}{l}\text { Lady Servants } \\
\qquad(n=71)\end{array}$} \\
\hline & $\begin{array}{c}\text { Adjusted OR } \\
\qquad(95 \%)\end{array}$ & P-value \\
\hline $\begin{array}{l}\text { Awkward positions (49): } \\
\text { Repetitive movements (54): }\end{array}$ & $\begin{array}{c}4.1(2.4-6.8) \\
3.6(2.31-5.2)\end{array}$ & $\begin{array}{l}0.002 * \\
0.001 *\end{array}$ \\
\hline $\begin{array}{r}\text { Age (years): } \\
-\quad \leq 40 \\
-\quad>40\end{array}$ & $\begin{array}{l}1.22(0.12-1.9) \\
3.4(2.12-6.21)\end{array}$ & $\begin{array}{c}0.123 \\
0.000^{*}\end{array}$ \\
\hline $\begin{array}{ll}\text { Body mass index }(\mathbf{k g} / \mathbf{m} 2): \\
- & \text { Over weight } \\
- & \text { Obese }\end{array}$ & $\begin{array}{l}1.2(0.6-1.8) \\
3.1(2.4-7.2)\end{array}$ & $\begin{array}{l}.125 \\
.005^{*}\end{array}$ \\
\hline \begin{tabular}{ll}
\multicolumn{2}{l}{ Distress Yes } \\
$-\quad$ score $>15$ \\
$-\quad$ score $>20$ \\
\end{tabular} & $\begin{array}{l}1.2(0.8-2.7) \\
2.5(1.4-3.2)\end{array}$ & $\begin{array}{c}0.072 \\
0.012 *\end{array}$ \\
\hline $\begin{array}{l}\text { Number of children } \\
-\quad 1-2 \\
-\quad \geq 3\end{array}$ & $\begin{array}{l}1.2(0.87-3.3) \\
1.8(1.2-2.2)\end{array}$ & $\begin{array}{c}.123 \\
0.034 *\end{array}$ \\
\hline
\end{tabular}

*: Significant

This table shows multiple logistic regressions resulted in a best model that included awkward postures, repetitive movements during work, age, weight, distress and number of children. Awkward positions, repetitive body movements during work and age more than 40 years show the most significant independent risk factors for musculoskeletal disorders $(\mathrm{OR}=4.1,3.6,3.4)$ respectively followed by obesity $(\mathrm{OR}=3.1)$ then servants with distress score $>20(\mathrm{OR}=2.5)$. Also, servant having $\geq$ 3children $(\mathrm{OR}=1.8)$ has significant association with musculoskeletal disorders. 


\section{Discussion}

Domestic workers or servants have been generally ignored when addressing MSDs. A limited number of studies have particularly explored the prevalence, body distribution and causes of MSDs among full-time servants. So, in this study we tried to explore these issues.

This study revealed that full time servants in Doqqi area of Cairo were relatively young below 40 years old, all of them were female, most of them were illiterate, more than half of them claimed enough income but few of them were smokers. Also, almost half of domestic workers were overweight, most of them are unmarried, large numbers of lady servants had $\geq 3$ children and the majority of them had duration of work less than 20 years ,worked with awkward postures as well as used repetitive movements during work.

About eighty four percent of the studied group had musculoskeletal troubles (ache- pain-discomfort) at any time during past 12 months , 65\% from them being prevented from doing their normal work due to that trouble in the same period (last 12 months) and $77.5 \%$ of servants had that trouble at any time during the last 7 days. This was consistent with Frumin et al. (2006) who find that $71 \%$ of hotel housekeepers had musculoskeletal injuries in the period 2002 - 2005. Also, 42\% of restaurant waits staff reported experiencing musculoskeletal symptoms in the past year (2005) (Dempsey and Filiaggi , 2006) .While our result $(84.5 \%)$ was higher than that of the previous studies because of longer working hours, higher work load and more economic pressures on Egyptian full time servants.

The highest prevalence of musculoskeletal disorders was at lumbar region of the study group followed by one or both knees then wrist and hand and the least prevalence was at elbow region. These parts of the body were frequently affected because of prolonged awkward position of servants with repetitive movement during domestic work. The same results were obtained by

Salwe et al. (2011) who mentioned that ergonomic stressors were associated with pain in the back and upper and lower extremities among home makers.

On using General Health Questionnaire 12 items scoring system we found that $36.6 \%$ of servants have evidence of stress (score $>15$ ) and 19.7 $\%$ have severe stress $($ score $>20)$. These 
results indicated that full time servants complained of different degree of occupational stress which explained by feeling of fear during work at strange peoples, low look of the Egyptian society to servants, isolation from one's family, lack of paid vacation and sick or maternity leave as well as high work load of this occupation. These findings were almost in accordance with Habib et al. (2005) who reported that $43.5 \%$ of home makers complained of distress using the 12-item version of the General Health Questionnaire.

On multiple logistic regressions we found that lady servants with awkward postures and repetitive movements were the most significant predictors for MSDs among them. These findings were in accordance with Werner et al. (2005) who reported that repetitive hand movements were associated with upper extremity pain and discomfort. Also, a systematic review by Reid et al. (2010) reported that bending, kneeling and squatting have been linked to lower extremity pain. Housework tasks that typically require repetitive hand movements are generally performed by homemakers and may sometimes require awkward working postures which were potential risk factors for upper extremity, back and lower extremity MS pain (Habib et al. 2010).

As well as age more than 40 years showed significant association for musculoskeletal disorders which was attributed to the bad situation of musculoskeletal system with aging due to bad vascularity, osteomalacia and sedentary life style. This was congruent with Lee et al. (2013) who mentioned that the risk of developing work-related musculoskeletal symptoms was higher among older female hotel workers than those with younger ages.

Also, obese domestic workers came in the fourth rank risk factor that significantly associated with musculoskeletal disorders because increase in weight with body mass index more than or equal $30 \mathrm{~kg} / \mathrm{m} 2$ led to increase the load on joints and its damage if prolonged. Andersen et al. (2007) reported that a high body mass index was highly associated with MSDs especially lower limb pain among general working population.

Finally, the lowest significant independent predictors for musculoskeletal disorders in this study were found to be servants with distress score $>20$ (GHQ-12 items) followed by servant having $\geq 3$ children. Also, Habib 
et al. (2012) concluded that number of children $\geq 4$ for full time home makers as well as heavy stress among them were significantly associated with musculoskeletal pain .This could be related to the fact that child caring at home of servants made additional burden on musculoskeletal system and work stress may cause stress responses, which result in physiological actions contributing to MS pain.

\section{Conclusions and recommendations:}

Most of full time lady servants had musculoskeletal disorders $(84.5 \%)$ that mainly affected lumbar area followed by knee, wrist and hand areas. Also, 56.3\% of servants had mental stress and the most important risk factors that affect the MSDs were awkward positions, repetitive movements, age $\geq 40$ years, obesity, distress and number of children $\geq 3$ respectively. So, we recommended more health caring for this neglected category of population through health insurance system, ergonomic training programs for safe work without pain through ministry of health, employment of servants at well-defined places with determined limit for working hours and wages by ministry of manpower and immigration. Finally, pensions should be paid for those workers after they became old age and not able to work.

\section{Limitations of the study:}

The cross-sectional nature of our study did not permit inferences on the direction of causality for the relationship with distress. Further, the data obtained was self-reported; women may have provided answers that did not accurately characterize their health condition or behaviors, which may have led to a reporting bias. The double burden of women participating in the labor force involves several important social and physical implications; these were not addressed as they are beyond the scope of this paper, which was limited to.

\section{References}

1. Andersen JH, Haahr JP, Frost P (2007): Arthritis \& Rheumatism, Risk Factors for More Severe Regional Musculoskeletal Symptoms :A TwoYear Prospective Study of a General Working Population; 56(4):1355-1364.

2. Arcand R, Labrèche F, Stock S, Messing K, Tissot F (2000): Travail et santé [Work and health]. In: Daveluy C, Pica L, Audet $\mathrm{N}$, Courtemanche R, Lapointe F, editors. Enquêtesocialeet de santé 1998 [1998 Social and health questionnaire]. 2nd ed. Québec City, QC, Canada: Institut de la statistique du Québec; 525-70.

3. Ariens GA, Bongers PM, Hoogendoorn WE, Houtman IL, van der Wal G, van Mechelen W (2001): High quantitative job demands and low coworker support as risk factors for neck pain: results of a prospective cohort study. Spine; 26:1896-901; discussion 1902-3. 
4. Ariens GA, Van Mechelen W, Bongers PM, Bouter LM, Van der Wal G (2000): Physical risk factors for neck pain. Scand J Work Environ Health; 26:7-19.

5. Brulin C, Winkvisit A, Langendoen S (2000): Stress from working conditions among home care personnel with musculoskeletal symptoms. J Adv Nurs; 31(1):181-189.

6. Dempsey PG and Filiaggi AJ (2006): Crosssectional investigation of task demands and musculoskeletal discomfort among restaurant wait staff, Ergonomics;49(1): 93-106.

7. El Rufaie OE and Daradkeh TK (1996): Validation of the Arabic version of the thirty and twelve item general health questionnaires in primary care patients. British Journal of Psychiatry; 162(5): 662-664. [Pub Med: 8932899].

8. European Agency for Safety and Health at Work (2010): "Work-related musculoskeletal disorders in the EU-facts and figures," European Risk Observatory Report. Available http://www.themusculoskeletalelf. net/are-school-teachers-at-a-high-risk-ofdeveloping-musculoskeletal-disorders/\#sthash. Qd9hTAvW.dpuf.

9. Frumin E, Moriarty J, Vossenas P, Krause N, Halpin J, Orris P and Punnett L (2006): WorkRelated Musculoskeletal Disorders among Hotel Housekeepers: Employer Records Reveal a Growing National Problem. Contact: Eric Frumin, 212.352.4720/efrumin@unitehere.org.

10. Goldberg D and Williams P (1988): A user's guide to the General Health Questionnaire. Windsor: NFER Nelson.

11. Habib RR, Fathallah FA , Messing K (2010): Full time homemakers: workers who cannot 'go home and relax'. International Journal of Occupational Safety and Ergonomics; 16: 113128.

12. Habib RR, Hamdan M, Nuwayhid I, Odaymat F (2005): Musculoskeletal Disorders among
Full-Time Homemakers in Poor Communities. Women Health; 42(2): 1-14

13. Habib RR, Zeinb KEl, Hojeijb S (2012): Hard work at home: musculoskeletal pain among female homemakers, Ergonomics, Journal of Environmental and Public Health; 55(2):201211.

14. IBM (2010): IBM SPSS Statistics 19 Core System Users' Guide. SPSS Inc, Chicago [http:// www.IBM-SPSSStatistics-User_s-Guide.pdf].

15. Kuorinka I, Jonsson B, Kilbom AV, Interberg $\mathrm{H}$, Biering-Sorensen F, Andersson $\mathrm{G}$ et al (1987): Standardized Nordic Questionnaires for the analysis of musculoskeletal symptoms. Appl Ergon; 18:233-7.

16. Laperriere E, Ngomo S, Thibault MC, Messing K (2006): Indicators for choosing an optimal mix of major working postures. Appl Ergon; 37:349-57.

17. Lee J, LeeJ, Mun H, Lee K, Kim J (2013): The Relationship between Musculoskeletal Symptoms and Work-related Risk Factors in Hotel Workers. Annals of Occupational and Environmental Medicine; 25:20.

18. Mattila M, Vilkki M. OWAS Methods. In: Karwowski W, Marras WS, editors. (1999): The Occupational Ergonomics Handbook. CRC Press LLC: USA; p. 447-59.

19. Messing K, Stock SR, Tissot F (2009): Should studies of risk factors for musculoskeletal disorders be stratified by gender? Lessons from the 1998 Québec Health and Social Survey. Scand J Work Environ Health; 35(2):96-112.

20. Messing K, Tissot F, Stock SR (2006): Lower limb pain, standing, sitting and walking: the importance of freedom to adjust one's posture. In: Pikaar RN, Koningsveld EAP, Settels PJM, editors. Proceedings of the 16th Congress of the International Ergonomics Association, Maastricht, Netherlands [CD-ROM]. Amsterdam, the Netherlands: Elsevier. 
21. Muirden KD (2005): Community oriented program for the control of rheumatic diseases: studies of rheumatic diseases in the developing world. Curr Opin Rheumatol; 17:153-6.

22. National Research Council/Institute of Medicine (2001): Musculoskeletal disorders and the workplace: low back and upper extremities. Washington, DC, USA: National Academy Press

23. Picavet H and Shouten J (2003): Musculoskeletal pain in the Netherlands: Prevalence, consequences, and risk groups, the DMC3study. Pain; 102(1-2):167-178. Doi: 10.1016/ s0304-3959(02)00372-x. [PubMed: 12620608].

24. Punnett L and Wegman DH (2004): Workrelated musculoskeletal disorders: the epidemiologic evidence and the debate. J Electromyogr Kinesiol; 14:13-23.

25. Reid CR, Bush PM, Karwowski W, Durrani SK (2010): Occupational postural activity and lower extremity discomfort: a review. International Journal of Industrial Ergonomics;40: 247-256.

26. Rosano A, Moccaldi R, Cioppa M, Lanzieri G, Persechino B, Spagnolo A (2004): Musculoskeletal disorders and housework in Italy. Ann Ig.; 16:497-507. In Italian.
27. Salwe K, Shrawan K, Hood J (2011): Non-fatal Occupational Injury Rates and Musculoskeletal Symptoms among Housekeeping Employees of a Hospital in Texas. Journal of Environmental and Public Health; Article ID 382510, pp7, doi:10.1155/2011/382510.

28. Viikari-Juntura E, Martikainen R, Luukkonen R, Mutanen P, Takala EP, Riihimaki H (2001): Longitudinal study on work related and individual risk factors affecting radiating neck pain. Occup Environ Med.; 58:345-52.

29. Werner RA, Franzblau A, Gell N, Ulin SS, Armstrong TJ (2005): Predictors of upper extremity discomfort: a longitudinal study of industrial and clerical workers. Journal of Occupational Rehabilitation; 15: 27-35

30. Yip Y, Ho S, Chan S (2001): Sociopsychological stressors as risk factors for low back pain in Chinese middle-aged women. $\mathbf{J}$ Adv Nurs.; 36:409-16.

31. Yip Y, Ho S, Chan S (2004): Identifying risk factors for low back pain (LBP) in Chinese middle-aged women: a case-control study. Health Care Women Int.; 25:358-69. 